\title{
SOYADI ÜZERİNE GÜNCEL HUKUKÎ SORUNLAR
}

\author{
Süleyman YILMAZ* \\ Gökçe Filiz ÇAVUŞOĞLU**
}

\section{$\ddot{O} Z$}

Toplumun oluşumu, stnıf kavramı ile başlamıştır. İnsanlık tarihin ise, sınıf kavramından bireyin kimliğine gidis hali yaşanmıştır. Hem birey hem de sinif, toplumu şekillendirmede önemli bir rol oynar. Bu sebeple, ikisinin de ayırt edilebilmesi gerekir. Geçmişte ve günümüzde yegâne ayırt etme aracı ise soyadıdır. Bu çalışmamamızda öncelikle soyadı kavramının tanımı yapılmaktadır. Ardından soyadı kavramının getirmiş olduğu sorunlar ele alınmaktadır. Bunu yapabilmek için sırasıyla kadının, çocuğun ve erkeğin soyadlart incelenmektedir. Kadının soyadının evlenme ve boşanma halindeki durumu ve mevcut düzenlemelerin anayasaya aykırı olup olmadığ tartışılmaktadır. Daha sonra, çocuğun soyadı ve Anayasa Mahkemesinin tutumu irdelenmektedir. Erkeğin soyadı konusu da detaylı bir şekilde ele alınmaktadır. Son olarak soyadı kavramı üzerine yapılan tartışmalara çözüm sunduğumuz ortak soyadı ilkesi açılklanmaktadır.

Anahtar Kelimler: Soyadı, Çocuk hakları, Kadın Hakları, Kamu Düzeni, Eşitlik

\section{CURRENT LEGAL PROBLEMS ON SURNAME}

\section{ABSTRACT}

The formation of the society started with the concept of class. On the other hand, the history of humanity has gone from the concept of class to the identity of the individual. Both the individual and the class play an important role in shaping society. Therefore, both must be distinguished. The only means

\footnotetext{
* Doç. Dr., Ankara University, Faculty of Law, Department of Civil Law (syilmaz@law. ankara.edu.tr). ORCID ID: 0000-0002-7779-0528

** Ankara University, Faculty of Law, LLM Candidate (filizcavusoglu@hotmail.com).

ORCID ID: 0000-0002-6753-6032

DOI $\quad: 10.34246 /$ ahbvuhfd. 682733

Yayın Kuruluna Ulaştığı Tarih : 24/01/2020

Yayınlanmasının Uygun Görüldüğü Tarih: 29/01/2020
} 
of differentiating in the past and present is the surname. In this study, first of all, the surname concept will be defined. Then the problems arising out of the surname concept will be discussed. In order to do this, the surnames of women, children and men will be examined respectively. The status of the woman's surname in marriage and divorce and whether the current regulations are unconstitutional or not will be explained. Then, the surname of the child and the attitude of the Constitutional Court will be examined. The subject of the man's surname will also be detailed. Finally, we will explain the common surname principle that we provide solutions to the discussions on the concept of surname.

Keywords: Surname, Children's Rights, Women's Rights, Public Interest, Equality

\section{Giriş}

İnsanlar, birey olarak bazı ihtiyaçlarını karşılayamadıklarını fark ettikleri an toplumu oluşturdular. Aynı zamanda adil bir düzen oluşturmak gayesiyle bazı haklarından feragat ederek haklarını devlet adındaki suni yapıya devrettiler. Devlet ise onları tanımak ve bir statüye sokmak adına insanlara bir ad vermiştir. Her sınıfın bir adının olması gerektiği ve her sınıftan gelen bireyin bu adla anılması gerektiği fikri insanlar arasında yerleşmiştir. Dolayısıyla her bir sınıf bir ad almıştır. Sonrasında toplumsal değişikliklerle birlikte aileler bir ad ile çağrılmaya başlanmıştır. Ailenin adı kişinin soyunu gösterdiği için aile adına soyadı denmiştir.

Soyad1, kişiyi bir aileye ait hissettiren; ona bir kimlik veren bir kavram olarak ortaya çıkmıştır. Kişi, soyadı sayesinde soyu ile bağ kurabilir ve soyunu öğrenebilir hale gelir. Kişinin soyunu öğrenme hakkı da bir insan hakkı olarak kabul edilmeye başlandığı için soyadı kavramı da önem arz eder hale gelmiştir.

Soyadı, kişinin doğduğu ailenin soyadını almasıyla başlayan ve bazı hallerde değiştirilebilen bir addır. Eşitlik, kamu düzeni, aile ve gelenekler gibi faktörlerin de göz önünde tutulmasıyla birlikte soyadı için getirilen düzenlemeler, farklı hukuk sistemlerinde değişik şekillerde ele alınmıştır. Ancak modern hukuk sistemlerinde, Avrupa İnsan Hakları Sözleşmesi sebebiyle pek çok ülke, kadın-erkek eşitliğine uygun olarak soyadını düzenlemiştir. 
Türkiye'deki düzenleme ise, kadının ve çocukların soyadına ilişkin ayrıntılı hükümler içermektedir. Ancak bu düzenlemeler bazen değişen topluma tekrar uyarlanmaya ve yorumlanmaya ihtiyaç duymaktadır. Günümüzde bazı düşünürler ${ }^{1}$ ve bazı yasalar ${ }^{2}$, ortak soyadına ihtiyaç duyulmayacağı, şu an ki düzenlemelerin Avrupa İnsan Hakları Sözleşmesi'ne aykırı olduğunu ileri sürmüştür. Bu görüşe göre, evlilikle beraber eşler dilerlerse kendi soyadlarını kullanmaya devam edebilir ${ }^{3}$. Yani evlilikle eşler ortak soyadı taşımak zorunda değildir.

Bireyin topluma karşı, toplum da bireye karşı korunması gerekir. $\mathrm{Bu}$ korunmayı kamu düzeni denilen ince çizgi oluşturur. Bu sebeple biz ortak bir soyadının olması ve çocukların da bu ortak soyadını taşıması gerektiği kanısındayız. Ancak sadece kocanın soyadının ortak soyadı olarak kullanıldığ bir düzenlemenin hukuka aykırı olduğu kanaatindeyiz. Zira bu eşitlik ilkesine aykırıdır. Bizce aile ortak bir soyadı ile temsi edilmeli ve eşler bu ortak soyadını beraber seçmelidir.

Çocuğun soyadı ise ailenin evli olup olmadığına göre farklılık arz eder. Ayrıca boşanmanın çoğun soyadına bir etkisinin olup olmayacağı da güncel bir hukukî sorundur. Bu çalışmamızda hem kadın hem erkek ve hem de çocuğun soyadına ilişkin sorunlar ele alınmaktadır.

\section{Soyadı}

\section{A. Soyadı Kavramı}

Ad ve soyadı, insanın sadece ölümsüzlüğe kavuşmasına neden olmaz; aynı zamanda kişide bir aidiyet duygusu oluştur ve ona bir kimlik kazandırır. Bunun sonucu soyadı kavramı da en temel insan haklarındandır. Ayrıca soyadı kavramı; İnsan Hakları Sözleşmeleri’ne, Çocuk Hakları Sözleşmesi’ne konu olmuş önemli bir haktır.

Soyadı, bir kimsenin öz adından hemen sonra gelen, soyunu belirten ve taşınması zorunlu olan aile adıdır ${ }^{4}$. Soyadı, kişiye sıkı sıkıya bağlı, vazgeçilmez

\footnotetext{
AYAN, s.40.

2 Bkz. Almanya, Avusturya, Fransa, İtalya ve İsviçre Hukuku.

3 AYAN, s. 40 vd.

4 MEIER/STETTLER, s. 353; OĞUZMAN / SELIÇĊ /OKTAY-ÖZDEMIR, s. 107; DURAL /ÖĞÜZ, s.166; GERMEÇ, s. 67; ERDOĞAN, s. 705; MOROĞLU, s. 245; ÖZTAN, s.164; ABİK, s. 23, 31. AYM, E. 2011/51, K. 2012/32, T. 1.3.2012 (Kazancı Veri Tabanı, Erişim 15.11.2019).: "Soyad, belli bir ailenin bireylerini diğer ailenin bireylerinden ayırmaya
} 
ve devredilmez bir haktır. Hatta soyadının miras açılmadan mirasçılara intikal eden bir miras olarak değerlendirmekte mümkündür ${ }^{6}$. Zira kişi doğduğu anda ailesinin soyadını alır.

21 Haziran 1934 tarihli ve 2525 sayıl Soyadı Kanunu ile her bir vatandaşının soyadı taşıma zorunluluğu getirilmiştir?. Bu sebeple soyadı taşımak hem bir hak, hem de bir ödevdir.

\section{B. Amacı}

Soyadı, toplumda bir düzeni sağlamak, kişileri ayırt edilebilir kılmak adına getirilmiş bir düzenlemedir'. Genel olarak soyadının amacı, her bir aileye bir ad vererek kişilerin hem ait oldukları aileyi belirlemede kolaylık sağlamak, hem de toplumsal düzeni sağlamaktır ${ }^{9}$. Her bir aileye yeni katılan üye, ailenin adını alır ve böylelikle ailedeki bireyler vefat etseler bile soyadları yaşamaya devam eder ${ }^{10}$.

Soyadının düzenlenmesi kişilik haklarının ${ }^{11}$ ve ailenin korunmasına hizmet etmektedir ${ }^{12}$. Soyadının ortaya çıkış amacının kamu düzeni olduğunu söylemek yanlış olmaz. Zira devletler yurttaşlarını birbirinden ayırmak, hatalı işlem yapmamak, yurttaşın işlemlerinin yapılmasını kolaylaştırmak amacıyla, soyadını, kimliği ayırt etmeye yarayan unsur olarak ortaya çıkartmışıı' ${ }^{13}$.

\section{Soyadının Kullanımı ve Kazanılması}

Dünyada soyadının yaygın kullanılış şekli, kişinin isminden sonra bir ek olarak soyadının kullanılmasıdır. Bazı kültürlerde ise soyadı, isimden önce

yarayan ve kuşaktan kuşağa geçen addır. Bir kimsenin kimliğinin belirlenmesinde en önemli unsur olan soyad, vazgeçilmez, devredilmez, feragat edilmez ve kişiye sikl surette bağll bir kişilik hakkıdır. Soyadı üzerindeki hak, mutlak haklardan olması nedeniyle herkese karşı ileri sürülebilmekte ve yasayla özel olarak korunmaktadır".

5 OĞUZMAN/SELIÇ்̇/ OKTAY-ÖZDEMIR, s. 106; TACİR, s. 51.

6 MOWAT, s. 323.

7 OĞUZMAN/SELIÇİ/ OKTAY-ÖZDEMIR, s. 107; DURAL/ÖĞÜZ, s. 166; ÖZTAN, s. 164; BALSOY, Gülhan: s. 159.

8 ÖZEN, s. 171-172.

9 DURAL/ÖĞÜZ, s. 167; AYAN, s. 20; ÖZEN, s. 172.

10 BAYGIN, s. $97 \mathrm{vd}$.

11 Kişilik haklarının tanımı için Bkz. DURAL / SARI, s. 162.

12 ÖZEN, s. $171 \mathrm{vd}$.

13 DURAL/ÖĞÜZ, s. 167; BAŞOĞLU, s.352 vd. 
de gelebilmektedir. Ancak genel eğilim addan sonra soyadının kullanılması şeklindedir.

Her bir yurttaşın soyadının olması gerektiği için, soyadının kazanılması konusu gündeme gelmiştir. Her bir aile, soyadını kanunun yürürlüğe girmesiyle birlikte, kendilerine uygun bir soyadı seçip nüfusa bildirmişlerdir. Ancak toplumsal değişiklikler, yeni evlilikler gibi nedenlerle insanların soyadlarını değiştirmeleri gerekmiştir. Bu sebeple soyadı sadece soy bağ 1 yoluyla değil, aynı zamanda evlenme yoluyla, evlat edinme yoluyla, idari kararla, soyadı seçme ${ }^{14}$ yoluyla da kazanılır hale gelmiştir ${ }^{15}$.

\section{Soyadı Kavramının Getirdiği Problemler}

Soyadının kazanılması ve bazı hallerde de değiştirilebilmesi gerekmektedir. Özellikle evlenme, boşanma gibi durumlarda soyadı kullanımı ile ilgili hukukî sorunlar ortaya çıkmaktadır. Kadınların, çocukların ve erkeklerin soyadı sebebiyle karşılaştıkları hukukî sorunlar aşağıda detaylı bir şekilde ele alınmıştır.

\section{A. Kadının Soyadı}

\section{Genel Olarak}

Kadının soyadını etkileyen üç önemli olay vardır. Bunlar, doğum, evlenme ve boşanmadır. Kadın, doğumu ile ailesinin soyadını alır. Evlenme ve boşanma halinde ise kadının soyadı değişmektedir. Kadın evlenene kadar ailesinin soyadını taşımaktadır. Evlendikten sonra, kadının soyu değişmemesine rağmen soyadı kanun gereği değişmektedir.

\section{Evli Kadının Soyadı}

\section{a. Genel Olarak}

Eski Medeni Kanun döneminde, kadının evlendikten sonra kocasının soyadını alması gerektiği kendi ailesinin soyadını kullanmaya devam

\footnotetext{
14 TMK m. 27: "Adın değiştirilmesi, ancak haklı sebeplere dayanılarak hâkimden istenebilir. Adın değiştirildiği nüfus siciline kayıt ve ilan olunur. Ad değişmekle kişisel durum değişmez. Adın değiştirilmesinden zarar gören kimse, bunu öğrendiği günden başlayarak bir yıl içinde değiştirme kararının kaldırılmasını dava edebilir”; 18. HD., E. 2006/562, K. 2006/1634, T. 2.3.2006 (Kazanc1 Veri Tabanı): "Adin değiştirilmesi, ancak haklı nedenlere dayanılarak hâkimden istenebilir ise de kişiye sıkı sıkıya bağlı olan ad üzerindeki bu hakkl, kişinin kendisinden başkası kullanamaz".

15 OĞUZMAN/SELIÇİ/ OKTAY-ÖZDEMİR, s. 109 vd; ÖZTAN, s. 164.
} 
edemeyeceği emredici şekilde düzenlenmişti. Modern akımlardan etkilenen yeni Medeni Kanunda, kadınların, kocalarının soyadlarının yanında ailelerinin soyadlarını da taşıyabileceği düzenlenmiştir ${ }^{16}$. Zira TMK. m. 187'e göre "Kadın, evlenmekle kocasinın soyadını alır; ancak evlendirme memuruna veya daha sonra nüfus idaresine yapacağ yazll başvuruyla kocasının soyadı önünde önceki soyadını da kullanabilir. Daha önce iki soyadı kullanan kadın, bu haktan sadece bir soyadı için yararlanabilir".

Genel kabule göre, toplumda ailenin bir ortak soyadının bulunmas1 gerekmektedir. Yeni bir aile kuran kadın ve erkeğin, ortak soyadını taşıması gerekir. Erkek, egemen bir kültürün de etkisiyle ailenin erkeğin soyadını alması gerektiği kabul edilmiş ve bu kabul yasalara yansımıştır ${ }^{17}$. Zira kadının soyadını düzenleyen TMK. m. 187'ye göre evlenen kadın, kocasının soyadını alır. Bu hükmün, emredici niteliği gereği, kadının eşinin soyadını almaktan başka bir seçeneği yoktur ${ }^{18}$. Ancak kadının talep etmesi durumunda kadın evlenmeden önceki soyadını da kocasının soyadı ile birlikte kullanmaya devam edebilir ${ }^{19}$. Bu durumda evli kadının iki tane seçimlik hakkı bulunmaktadır; ya kocasının soyadını kullanır ya da kendi kızlık soyadının arkasına kocasının soyadını alarak soyadını kullanır. Bunun dışında kadının kocasının soyadını almamayı tercih etme hakkı bulunmamaktadir ${ }^{20}$.

\section{b. TMK. m. 187'nin Anayasaya ve Uluslararası Anlaşmalara Uygun Olup Olmadığı}

"Adl olan her şey mevcuttur"21. Bir şeyin adı değiştirildiğinde aslında onun varlığ ve kimliği ile oynanmış olur. Bu sebepledir ki, tarih sahnesinde bir yerde otorite kurmak isteyenler, egemen kültürlerini orada göstermek için bölgelerin adlarını değiştirmişlerdir. Adı değiştirmek kimliği değiştirmektir. Ad sadece birkaç harften ibaret değildir. Bir kimsenin benliğini, kültürünü ve onu o yapan pek çok şeyin sembolüdür. Evlilik yoluyla kadının kimliğinin değiştirilmesinin ne kadar doğru olduğu bu yüzden hep tartışılmıştır. Zira bu durum, hem eşitlik hukukuna, hem de temel hak ve özgürlükler hukukuna aykırılık oluşturabilir. Anayasa hukukuna hâkim olan ilkelerden birisi de,

16 GENÇCAN, s. 436.

17 HATEMİ, Hüseyin/ KALKAN-OĞUZTÜRK, s. 54.

18 ÖCAL-APAYDIN, s. 436.

19 GÖZTEPE, s. 121 vd.; ÖCAL-APAYDIN, s. 436.

20 ÖCAL-APAYDIN, s. 436.

21 Bkz. Hamdi Tanpınar, Saatleri Ayarlama Enstitüsü.

8 Ankara Hacı Bayram Veli Üniversitesi Hukuk Fakültesi Dergisi C. XXIV, Y. 2020, Sa. 1 
insan haklarına saygılı devlet ilkesidir ${ }^{22}$. Kişinin soyadı taşıması da, soyunu bilme hakkı da, bir insan hakkı olarak değerlendirilmektedir. Bu nedenle, sadece kadından soyadını değiştirmesinin istenmesi, anayasaya aykırı kabul edilebilir.

Erkeğin soyadı değişmezken, kadından evlenmesi durumunda kimliğini değiştirmesini istemek, eşitlik hukukuna aykırı olabileceği düşünülebilir. Ancak, İsviçre hukuku, ailenin daha üst bir yap1 olduğundan yola çıkarak, cinsiyet eşitliğini de bozarak, erkeğin soyadının alınmasının uygun olacağı yönünde düzenlemeler getirmiştir ${ }^{23}$. Ancak daha sonrasında, aile adı için cinsiyet eşitliğinin bir taraf lehine bozulmasının yıkıcı etkilerinden kurtulmak adına, İsviçre'de kadınların kızlık soyadları ile kocalarının soyadlarını beraber kullanabilecekleri kabul edilmiştir ${ }^{24}$. Bununla birlikte günümüzde modern hukuk sistemlerinde kadının ve erkeğin soyadı konusunda eşit olması gerektiği kabul görmektedir ${ }^{25}$.

Anayasa m.10'da aç1kça “Kadınlar ve erkekler eşit haklara sahiptir. Devlet, bu eşitliğin yaşama geçmesini sağlamakla yükümlüdür" ifadesine yer verilerek cinsiyete dayalı bir ayrıcalığın yasalarla düzenlenemeyeceği ifade olunmuştur. Ayrıca, İstanbul Sözleşmesi, toplumsal cinsiyete dayalı ayrımcılık ve şiddeti temel almış olmakla birlikte, toplumsal cinsiyet kavramını detaylı bir şekilde tanımlayan ilk uluslararası anlaşmadır ${ }^{26}$. Söz konusu anlaşma ile taraf devletler, kadın ve erkeğin toplumda her alanda hukuken eşit olacakları yönünde taahhüt vermiştir. Ancak Anayasaya ve İstanbul Sözleşmesi'ne rağmen, sadece kadının eşinin soyadını alabileceği öngörülmektedir. Bu durumda mevcut düzenleme kadın ve erkek arasındaki eşitliği bir taraf lehine bozduğu için Anayasaya ve İstanbul Sözleşmesi’ne aykırıdır.

\section{c. Türk Yargısının ve AHİM'in Kadının Soyadına İlişsin İzlediği}

\section{Tutum}

\section{aa. Türk Yargısı}

Kadın ve erkek eşitliğinin vurgulandığı bir diğer sözleşme ise, Avrupa İnsan Hakları Sözleşmesi'dir. Yalnızca cinsiyete dayalı farklı

\footnotetext{
22 GÖREN, s. 90 vd.

23 ÖCAL-APAYDIN, s. 430; AYAN, s. 40.

24 ÖCAL-APAYDIN, s. 430; AYAN, s.40.

25 ATASAYAN, s.200 vd.

26 BAKIRCI, s. 135.
} 
bir düzenlemenin Türkiye'nin de taraf olduğu Avrupa İnsan Hakları Sözleşmesi'ne uygun olduğunun kabul edilebilmesi için, çok geçerli nedenlerin sunulması gerekmektedir ${ }^{27}$. Yargitay Hukuk Genel Kurulu, emsal teşkil eden somut bir olayda, evli erkeklerin evlenmeden önceki soyadlarını kullanabilmelerine karşın evli kadınların evlendikten sonra yalnızca kızlık soyadlarını kullanamamalarının benzer konumdaki kişiler arasında cinsiyete dayalı farklı muamele olarak değerlendirilebileceğini vurgulamıştır ${ }^{28}$. Zira Yargitay "Hemen ifade edilmelidir ki; farklı muameleyi haklı çıkartacak ikna edici gerekçeler gösterilmediği müddetçe 14. maddenin ilkesel olarak, erkek ve kadına eşit şekilde uygulanması zorunludur" demiştir ${ }^{29}$.

Söz konusu karar, kadının soyadı konusunda bir devrim niteliğindedir. Kadının, bekârken kullandığı soyadını kullanılmasının, aile birliğinin sağlanmasına negatif etkisi olacağı savunmasına karşı, aile birliğinin sağlanmasında ortak bir soyadın kullanılmasının etkinliği olmayacağı kabul edilmiştir. Ayrıca Yargitay Hukuk Genel Kurulu, ortak soyadı kullanımının sadece geleneksel yaklaşımın sonucu olduğunu söylemiştir. Keza Yargıtay Hukuk Genel Kurulu, evli bireylerin ortak soyadı kullanmaması halinde, nüfus hizmetlerinin yürütülmesinde ortaya çıkabilecek birtakım aksaklıların da teknik düzenlemeler ile aşılabileceğini kabul etmiştir. Yargıtay Hukuk Genel Kurulu, "evli kadınların aile birliği adına kocalarının soyadını taşımak zorunda birakılmalarının -önüne kendi kızlık soyadlarını ekleyebilseler denesnel ve makul bir nedeni olmadiğını..." kabul etmiştir.

\section{bb. AİHM}

Avrupa Birliğinde, soyadı konusunda birçok devletin bu alandaki iç hukuk hükümlerini değiş̧irdiği görülmektedir. Fakat bazı üye devletlerin, bunu yapmadığ1, ancak yapması gerektiği yönünde bir karar verilmiştir. Avrupa Birliği hukukuna göre, âdet ve yerel gelenek çeşitliliğine saygı duyulmasının gerekmektedir. Ancak bu saygının sınırını da ayrımcılık yasağı belirmektedir. Soyadı konusunda, kadınlar aleyhine ayrımcılık yapan hükümler bulunan devletlerin, bu ayrımcılığı ortadan kaldırmak için gerekli önlemleri almaları gerektiği ifade edilmiştir. Türkiye'deki düzenlemeler ise, bireyin ve eşitliğin ön planda olduğu Avrupa İnsan Hakları Sözleşmesi'ne aykırı bulunmuştur.

27 Schuler-Zgraggen/İsviçre, 24 Haziran 1993 tarihli karar, Seri A sayı 263, § 67.

28 HGK, E. 2014/2-889, K. 2015/2011, T. 30.9.2015 (Kazancı Veri Tabanı, Erişim 14.11.2019).

29 HGK, E. 2014/2-889, K. 2015/2011, T. 30.9.2015 (Kazancı Veri Tabanı, Erişim 14.11.2019). 
Nitekim AİHM, Ünal Tekeli/Türkiye ${ }^{30}$, Leventoğlu Abdulkadiroğlu/Türkiye ${ }^{31}$, Tuncer Güneş/Türkiye ${ }^{32}$, ve Tanbay Tüten/Türkiye ${ }^{33}$, kararlarında cinsiyete dayalı farklı muamelelerin, AİHS 14 ve 8. maddelerine ve hukuka aykırı olduğunu belirtmiştir.

Ünal Tekeli-Türkiye davasında Ünal Tekeli, evlendikten sonra eşinin soyadını almak istememektedir. Ancak 1990 tarihinde yaptığı evlilik sonucu eşinin soyadını rızası olmaksızın kanun gereği almıştır. Meslek hayatında bekârlık soyadı ile tanındığı için kızlık soyadını da kullanmaya devam etmiştir. Bu uygulamanın eşitlik hukukuna aykırılığını ileri süren Tekeli, Avrupa İnsan Hakları Mahkemesinin önüne uyuşmazlığı taşımıştır. Bunun sonucu Türkiye aleyhine karar verilmiştir.

Kadının soyadına ilişkin olan bir diğer karar, Tanbay Tüten- Türkiye kararıdır. Başvuran, yetkililerin evlendikten sonra yalnızca kendi soyadını taşımasına izin vermemesinden şikâyet ederken, Türk yasalarının evli erkeklere, kendi soyadlarını taşımasına izin vermiştir, şeklinde beyanda bulunmuştur ${ }^{34}$. Bunun cinsiyete dayalı ayrımcılığa yol açtığını ve Sözleşme'nin 8. maddesiyle birlikte 14. maddeyle uyumsuz olduğu belirtilmiştir. Bu davanın sonucunda da Türkiye aleyhine karar verilmiştir ${ }^{35}$.

Görüldüğü üzere, Avrupa İnsan Hakları Mahkemesi, her konuda olduğu gibi kamu düzenini bu kadar etkileyen bir alanda da bireysel tutumunu bozmamış ve bireyin haklarını toplum düzenini nazara almadan korumaya çalışmıştır. Avrupa İnsan Hakları Mahkemesi'nin, Türk kanunlarının soyadı konusunda eşitlik ilkesini yansıtmadığına yönelik tespiti isabetlidir. Ancak ailedeki ortak soyadı kavramını yok etmeye yönelik kararlar, toplumun yap1 taşını oluşturan aileyi olumsuz yönde etkileyebilir. $\mathrm{Bu}$ da kamu düzeninin bozulması ile sonuçlanabilir.

\section{Boșanmıș Kadının Soyadı}

Boşanmanın hüküm ve sonuçlarından bir tanesi de soyadına ilişkindir. TMK. m. 173/I'e göre, boşanma halinde kadın, evlenmeden önceki soyadını

\footnotetext{
30 B. No: $29865 / 96,16 / 11 / 2004$.

31 B. No: 7971/07, 28/5/2013.

32 B. No: $26268 / 08,3 / 10 / 2013$.

33 B. No:38249/09, 10/12/2013.

34 DEMIR, s. 12.

35 Bkz. Tanbay Tüten v. Turkey, B. No 38249/09.
} 
yeniden alır. Ancak kadın evlenmeden önce dul idiyse, hâkimden bekârlık soyadını taşınmasına izin verilmesini isteyebilir.

Boşanma halinde, kadının talep etmesi durumunda, hâkim, kocasının soyadını kendi isminin önünde kullanmaya devam etmesine karar verebilir. Ancak kadının, bunun kocaya zarar vermeyeceğini ispatlaması ve kullanmada menfaati olduğunu ispatlaması gerekir (TMK. m. 173/II). Örneğin, kadın boşandığ1 eşinin soyadı ile ünlenmişse veya çocukları bulunuyorsa, anne çocuklarla aynı soyadını taşımak istiyorsa, kadının boşandığı eşinin soyadını taşımakta menfaati vardır denebilir.

\section{B. Çocuğun Soyadı}

\section{Medeni kanundaki Düzenleme}

\section{a. Genel Olarak}

Türk Medeni Kanun'un 321. maddesinde "Çocuk, ana ve baba evli ise ailenin soyadını taşır. Ancak, ana önceki evliliğinden dolayı çifte soyadı taşıyorsa çocuk onun bekârlık soyadını taşır" hükmüne yer verilerek soyadı müessesi düzenlenmiştir. Söz konusu kanun hükmü, defi yoluyla Anayasa Mahkemesine götürülmüştür. Anayasa Mahkemesi ana ve babanın evli olması durumunda, çocuğun aile adını taşınmasını öngören kısmı anayasaya aykırı bulunmamıştır. Fakat Anayasa Mahkemesi, bu maddenin birinci cümlesinde yer alan “... evli değilse ananın ..." ibaresini iptal etmiştir ${ }^{36}$.

Görüldüğg̈ üzere, Türk hukukunda çocuğun soyad1, çocuğun evlilik içinde doğup doğmamasına göre şekillenmektedir ${ }^{37}$. Evlilik içinde ya da herhangi bir nedenle evliliğin sona ermesinden başlayarak üç yüz içinde doğan çocuk, babasının soyadını alır. Evlilik dışında doğan çocuk, anasının ve babasının birbiriyle evlenmesiyle kendiliğinden evlilik içinde doğan çocuklara ilişkin hükümlere bağlı olur ve babanın soyadını alır. Evlilik dışında ya da evliliğin sona ermesinden başlayarak üç yüz günden sonra doğan çocuğun eskiden annesinin soyadını alacağı belirtilmişti ${ }^{38}$. Ancak bu hüküm Anayasa Mahkemesi tarafindan iptal edilmiştir. Kanun evlat edinilen çocuğun ise evlat edinenin soyadını alacağına hükmetmiştir.

\footnotetext{
36 AYM, 2/7/2009 tarihli ve E.: 2005/114, K.: 2009/105 sayılı kararı; KILIÇOĞLU, s.600.

37 KILIÇOĞLU, s. 600.

38 Bkz. Soyadı Nizamnamesi m. 15; ÖZDAMAR, s. 441 vd.
}

12 Ankara Hacı Bayram Veli Üniversitesi Hukuk Fakültesi Dergisi C. XXIV, Y. 2020, Sa. 1 
$\mathrm{Bu}$ açıklamalardan da anlaşılacağ şartlarda hangi soyadını alıp taşıyacağı yasalarla belirtilmiş olup anne veya babanın çocuğun soyadını seçmesi mümkün değildir ${ }^{39}$.

\section{b. Evlilik İçinde Doğan Çocuğun Soyadı}

Çocuğun annesi ve babasının evli olması durumunda çocuk ailenin ortak soyadını alır. Bu durumda çocuklar babalarının soyadlarını alırlar ${ }^{40}$.

\section{c. Evlilik Dışı Doğan Çocuğun Soyadı}

Evlilik dışında ya da evliliğin sona ermesinden başlayarak üç yüz günden sonra doğan çocuğun eskiden annesinin soyadını alacağı belirtilmişti. Ancak bu hüküm Anayasa Mahkemesi tarafından iptal edilmiştir. Bu iptal kararı iki açıdan eleştirilmektedir. İlk olarak, söz konusu iptal kararı, aynı zamanda Nüfus Hizmetleri Kanunu'nun 28. maddesinin de örtülü olarak yürüklükten kaldırılması anlamına gelmektedir ${ }^{41}$. İkinci olarak, Anayasa Mahkemesi'nin ana ve baba evli değilse çocuğun anasının soyadını almasının çocuk yararına aykırılık oluşturabileceği düşüncesidir ${ }^{42}$. Bu iptalle sanki çocuğun babasının soyadını alması çocuğun daha menfaatine olacağı düşünüldüğü ifade edilmiştir ${ }^{43}$. Ancak pek çok ülkede evlilik bağı yoksa, çocuğun ananın soyadını alması gerektiği kabul edilmiştir. Kanımızca, Anayasa Mahkemesi’nin söz konusu iptal kararı isabetlidir. Zira Çocuk Hakları Sözleşmesi'nin 3. maddesinde "Kamusal ya da özel sosyal yardım kuruluşları, mahkemeler, idari makamlar veya yasama organları tarafindan yapılan ve çocukları ilgilendiren bütün faaliyetlerde, çocuğun yararı temel düşüncedir" denmiştir. Bu hüküm göz önünde bulundurulduğunda, evlilik dışı doğan çocuğun, annesinin veya babasının soyadını alacağını önceden belirlemek, çocuğun menfaati her olaya göre farlılık arz edebileceği için Çocuk Hakları Sözleşmesi’ne aykırılık teşkil etmektedir. Çocuğun evlilik dişında doğması durumda, annesinin veya babasının soyadını taşıması konusunda, onun menfaatine bakılmalı ve ona göre soyadı belirlenmelidir. Bu sebeple Anayasa Mahkemesi'nin kararı çocuğun menfaatine uygun bir karardır.

\footnotetext{
39 GERMEÇ, s. 68.

40 AYAN, s. 23.

41 AKKAYAN-YILDIRIM, s. 69-89; ACABEY, s.498.

42 AYAN, s. 26 vd; GERMEÇ, s. 67.

43 AYAN, s. 26 vd; GERMEÇ, s. 67.
}

Ankara Hacı Bayram Veli Üniversitesi Hukuk Fakültesi Dergisi C. XXIV, Y. 2020, Sa. 113 
Herhangi bir nedenle evliliğin sona ermesinden başlayarak üç yüz içinde doğan çocuk da tıpkı evlilik içinde doğan çocuk gibi babasının soyadını alır. Evlilik dışında doğan çocuk, anasının ve babasının birbiriyle evlenmesiyle kendiliğinden evlilik içinde doğan çocuklara ilişkin hükümlere bağlı olur ve babanın soyadını alır ${ }^{44}$.

\section{d. Evlat Edinilen Çocuğun Soyadı}

TMK m. 314'te yer alan düzenlemeye göre "Evlâtlık küçük ise evlât edinenin soyadını alır. Evlât edinen isterse çocuğa yeni bir ad verebilir. Ergin olan evlâtlık, evlât edinilme sırasında dilerse evlât edinenin soyadını alabilir". Bu durumda evlat edinilen küçük, ailenin soyadını alır. Ancak Ergin bir birey evlat ediniliyorsa kendisine seçim hakkı tanınmaktadır ${ }^{45}$. Evlat edinilen, ergin ise kendisine seçim yapma hakkı tanınır. Ergin evlat edinilen isterse evlat edinenin soyadını alır veya dilerse kendi soyadını kullanmaya devam eder.

\section{Boşanmanın Çocuğunun Soyadına Etkisi}

Boşanmanın hüküm ve sonuçlarından bazıları kadının soyadına ve velayete ilişkindir. Kadın boşanma ile birlikte bekârlık soyadını kullanmaya başlar. Buna karşılık çocuğun soyadı, boşanma ile birlikte kendiliğinden değişmemektedir. Ancak bazı toplumsal değişimler, kadınların toplumdaki statüsünün değişmesi, çocuğun menfaati gibi durumlar sebebiyle boşanma sonucu çocuğun soyadının değiştirilebileceği kabul görmeye başlamıştır ${ }^{46}$. Burada, boşanmadan sonra çocuğun soyadına ilişkin olarak Yargıtay ve Anayasa Mahkemesi'nin görüşünü incelemekte yarar vardır.

\section{a. Yargıtay'ın Çocuğun Soyadına İlişkin Vermiş Olduğu Karar}

Doktrinde $^{47}$, çocuk menfaatinin öne çıkması gerektiği, dolayısıyla çocuğun soyadının da çocuğun menfaati olduğu durumlarda değişmesi gerektiği savunulurken, Yargıtay bu görüşe katılmamaktadır. Zira Yargitay Hukuk Genel Kurulu vermiş olduğu bir kararda: "bir çocuğa soyadı verilmesi için o çocuğun doğum tarihinde anast ile babasının evli olup olmadiğına bakılması gerekir. Doğum tarihinde ana ve baba evli ise çocuk ailenin diğer bir anlatımla babanın soyadını alacaktır. Çocuğun soyadı bu surette belirlendikten sonra,

\footnotetext{
44 AYAN, s. 26 vd.

45 DURAL/ÖĞÜZ, s. 172; BAYGIN, s. 214.

46 KILIÇOĞLU, s. 601.

47 Çok menfaatinin çocuk hukukunda önde olduğuna yönelik Bkz. SEROZAN, s.162 vd.
}

14 Ankara Hacı Bayram Veli Üniversitesi Hukuk Fakültesi Dergisi C. XXIV, Y. 2020, Sa. 1 
onun soyadını velayet hakkına veya başka nedenlere dayanarak değiştirmek Türk Medeni Kanunu'nun 321. maddesindeki düzenleme karşısında mümkün değildir" demiştir ${ }^{48}$. Yargitay'a göre, evliliğin sonradan boşanma ile sona ermesi halinde velayet hakkının anneye verilmiş olması çocuğun soyadının değiştirilmesi için haklı bir neden sayılmaz ve mevzuat da buna izin vermez ${ }^{49}$. Yargıtay, mevzuatın boşanma sonrası çocuğun soyadının değişmesine izin vermediğini belirttikten sonra, mevzuat izin verseydi dahi sonradan gelişen sebeplerden dolayı çocuğun yararı açısından velayetin babaya yeniden verilmesi halinde bu kez baba velayet hakkına dayanarak tekrar çocuğun soyadını değiştirmek isteyebileceğini ve bununda kamu düzenine aykırılık oluşturabileceğini belirtmektedir. Zira Yargıtay'a göre, "velayet kimde ise çocuk onun soyadını taşıyacak o halde baba da bu haktan mahrum edilemez. Böyle bir uygulamanın nüfus kütüklerindeki kaydın güvenilirliği ve istikrarı zedeleyeceği gibi asıl bu gibi uygulamalar çocuğun ruh hali üzerinde çok derin ve etkili travma yaratacaktır. Yargı mercileri bu durumu gözeterek ana ile babanın ya da ailelerin çocuk üzerinden inatlaşarak onun yararlarını hiçe sayıp, hukuken oluşmuş statüleri gerçek dışı ve yapay sebeplerle değiştirmeye çalışmalarına izin vermemeleri, söz konusu istemlerine alet olmamaları gerekir" 50 .

Anayasa Mahkemesi, 1934 tarihli Soyadı Kanunun 4. maddesini de iptal ederek boşanmadan sonra velayet kendisine tevdi edilmiş annenin, kendi soyadını çocuğa verilebilmesinin yolunu açmıştır ${ }^{51}$. Buna rağmen Yargıtay, çocukların soyadının bu şekilde değiştirilmesini çocuk yararına aykırı gördüğü ve boşanan anneler tarafından açılan davalarda, yerel mahkemelerce verilen kabul kararlarını ve direnme kararlarını bozduğu görülmektedir ${ }^{52}$. Diğer bir ifade ile, Yargıtay nüfus sicillerinin sık1 sık değişime açık olması durumunun kamu düzenini bozacağını ve bu sebeple, boşanma sonucu velayeti elinde bulunduran tarafın çocuğun soyadını değiştirmeyi talep edememesi gerektiğini ifade etmektedir ${ }^{53}$.

48 HGK, E. 2013/18-2352, K. 2015/1710, T. 19.6.2015 (Kazanc1, Erişim 6.11.2019).

49 Bu yöndeki kararlar için Bkz. HGK, E. 2013/18-1755, K. 2015/1039, T. 13.3.2015 (Kazanc1 Veri Taban1, Erişim 6.11.2019); HGK, E. 2013/18-1658, K. 2015/997, T. 11.3.2015 (Kazanc1 Veri Tabanı, Erişim 6.11.2019).

50 Bkz. HGK, E. 2013/18-2352, K. 2015/1710, T. 19.6.2015 (Kazancı Veri Tabanı, Erişim 6.11.2019).

51 AYM, E. 2010/119, K. 2011/165, T. 8. 12.2011, RG. 14.02.2012.

52 GERMEÇ, s. 68.

53 Bkz. 18. HD.,E. 2009/10864,K. 2010/1097, T. 1.2.2010 (kazancı Veri Tabanı, Erişim 25.11.2019) :“4721 sayılı Türk Medeni Kanunu’nun 321. (önceki 743 sayılı Yasanın 259. 


\section{b. Anayasa Mahkemesi’nin Çocuğun Soyadına İlişkin Tutumu}

Anayasa Mahkemesi'nin 2015 yılı Mayıs ayından itibaren, boşanan ve çocuğunun velayetine sahip olan annelerin, çocuklarına kendi soyadlarını vermek için yapılan bireysel başvuru üzerine verdiği kararlarında, annelerin yapmış olduğu taleplerin reddetmesinin hukuka aykırı bulduğu ve hak ihlâli olduğuna karar verdiği görünmektedir. Anayasa Mahkemesi'nin, söz konusu kararı verirken üç temel unsuru göz önünde tuttuğu anlaşılmaktadır. Bunlar; aile hayatına saygı, eşitlik ve çocuğun menfaatidir.

Aile hayatına saygı ilkesi gereği, kadının da çocuğuna soyadını verebilmesi gerektiği ifade edilmektedir. Zira Anayasa Mahkemesine göre, "Aile yaşamindaki temel ilişkiler kadin ve erkek ile ebeveyn ve çocuk arasındaki ilişkilerdir. Resmî evlilik birlikleri kural olarak aile hayatı kapsamında güvence altına alınmakta olup evlilik içinde doğan çocuklar da kendiliğinden evlilik iliş̧kisinin bir parçası sayllırlar. Bu çerçevede, çocuğun doğumundan itibaren çocuk ve ebeveyn arasında aile yaşamı anlamına gelen bir bağ kurulduğunun kabulü gerekir" ${ }^{54}$. Boşanma sonrasında ise, velayeti alan anne ve çocuk arasında aile yaşamının kurulması önem arz etmektedir. Ancak anne ve çocuğun soyadının farklı olması bazı durumlarda ailenin kurulmasını olumsuz etkileyebilir. Bu da özel hayata saygı ilkesinin ihlâline sebep olabilir.

Bir diğer unsur ise eşitliktir. Eşitlik ilkesi hem başlı başına bir hak hem de diğer insan hak ve özgürlüklerinden yararlanılmasına hâkim, temel bir ilkedir ${ }^{55}$. Anayasa'nın 10. maddesi eşitlik ilkesinden faydalanacak kişi ve ilkenin kapsamı konusunda bir sınırlama getirmemiştir. Anayasa'nın 11. maddesinde yer alan "Anayasa hükümleri, yasama, yürütme ve yargl organlarını, idare makamlarını ve diğer kuruluş ve kişileri bağlayan temel hukuk kurallarıdır" hükmü uyarınca Anayasa'nın "genel esaslar" bölümünde düzenlenen eşitlik ilkesinin sayılan organlar, kuruluşlar ve kişiler açısından

) maddesi hükmüne göre doğru nesepli çocuk babanın (ailenin) soyadını taşır. Babanın soyadı veya çocuk reşit olduktan sonra kendi soyad, usulüne uygun olarak açacağı bir dava sonunda verilecek kararla değişmedikçe, çocuğun da soyadı değişmez. Bu durumda somut olayda baba kendi soyadını değiştirmediğine göre velayeti altındaki küçüklerin soyadlarının değiştirilmesi konusunda açtığ davanin reddi gerekirken, kabulüne karar verilmesi usul ve yasaya aykırıdır".

54 "Başvuru konusu olayda başvurucunun çocuğu evlilik içinde dünyaya gelmiş olup hukuken mevcut olan ailenin bir parçasıdır. Bu bağlamda boşanma davası sonucunda velayet hakkı kendisine tevdi edilmiş olan başvurucu ile çocuğu arasındaki söz konusu ilişsi aile yaşamının kurulması için yeterlidir".

55 ULUCAN, s. 371-372. 
da geçerli olduğu açıktır. Eklemek gerekirse, Anayasa'nın 10. maddesinin son fikrasında "Devlet organlarl ve idare makamları bütün işlemlerinde kanun önünde eşitlik ilkesine uygun olarak hareket etmek zorundadırlar" hükmüne yer verilmiştir. Bu hüküm uyarınca da yasama, yürütme ve yargı organları ve idari makamlar, eşitlik ilkesi ve ayrımcılık yasağına uygun davranmakla yükümlüdürler. Bir çocuğa soyadını sadece babanın verebilmesi ve annenin çocuğa soyadını verememesi kadın-erkek eşitliğine aykırılık yaratır. Bu da Anayasaya aykırıdır. Bunun sonucu Anayasa Mahkemesi de "Velayet hakkl ve bu bağlamdaki yetkilerin kullanımı da dâhil olmak üzere cinsiyetler arası eşitlik ve cinsiyete dayalı ayrımcllıkla ilgili hususlar, insan haklart ile ilgili birçok uluslararası hukuk belgesinde de yer almaktadı" demektedir ${ }^{56}$.

Anayasa Mahkemesinin değindiği son ilke ise çocuk menfaatidir. Zira Anayasa Mahkemesi çocukla ilgili işlemler yapılırken çocuğun menfaatinin de gözetilmesi gerektiğini de vurguladığı görülmektedir ${ }^{57}$.

Anayasa Mahkemesi, velayeti elinde bulunduran annenin çocuğa soyadını verebilmesi gerektiğinin, kadın-erkek eşitliği ilkesi ile ilişkili olduğu kanaatindedir. Kanaatimiz, her ne kadar Anayasa Mahkemesinin sonucu isabetli ise de, çocuğun soyadı konusunun daha çok çocuk hakları ile ilgili olduğu yönündedir.

\section{3. Çocuğun Soyadına Yönelik Değerlendirmelerimiz}

Anayasa Mahkemesi’nin, vermiş olduğu kararlarında, boşanma sonucu çocuğun soyadının değiştirilmesini, daha çok eşitlik ve aile hayatına saygı ilkesine dayandırdığı görülmektedir. Ancak, kanaatimiz, çocuğun menfaatinin daha önemli olduğu yönündedir. Çocuğun soyadı, Çocuk Hakları Sözleşmesi, eşitlik ilkesi ve özel hayatın gizliliği ilkesi göz önünde bulundurularak aşağıda ayrı ayrı değerlendirilmektedir.

\section{a. Çocuk Hakları Sözleşmesi Açısından Değerlendirme}

Çocuk hukukunda uluslararası toplum, çocuğun üstün yararı ilkesini benimsemiştir ${ }^{58}$. Söz konusu ilke, çocuğun üstün yararını belirlerken, onun

56 AYM, B.2013/2414, K. 6/1/2016, Resmî Gazete Tarihi: 29 Mart 2016 (Kazancı Veri Taban1, Erişim 6.11.2019).

57 AYM, B. 2013/9880 T. 11.11.2015; AYM, 2. B., B. 2014/1826 T. 20.7.2017 (Kazanc1 Veri Tabanı, Erişim 6.11.2019).

${ }_{58} \mathrm{Bu}$ ilke Birleşmiş Milletler Çocuk Haklarına Dair Sözleşme m.3; Çocuk Haklarının Kullanılmasına İlişsin Avrupa Sözleşmesi m.1; TMK m.339/1, 346/1: Çocuk Koruma 
bedensel, zihinsel, ruhsal, ahlâki ve toplumsal gelişiminin sağlanması amacının gözetilmesi gerektiğini belirtmektedir ${ }^{59}$. Ayrıca çocuk hukukuna hakim olan ilke, çocuğun yararının gözetilmesi ilkesidir ${ }^{60}$. Bu sebeple, çocuğun konu edinildiği bütün hukukî sorunlarda önce çocuğun yararı düşünülmelidir ${ }^{61}$. Bu sebeple sırf kadın-erkek eşitliği gerekçesiyle çocuğun soyadını belirlemek çocuk hukukuna aykırılık teşkil eder.

Çocuk Hakları Sözleşmesi'nin üçüncü maddesinde “Kamusal ya da özel sosyal yardım kuruluşlarl, mahkemeler, idari makamlar veya yasama organları tarafindan yapılan ve çocuklart ilgilendiren bütün faaliyetlerde, çocuğun yararı temel düsüncedir. Taraf Devletler, çocuğun ana-babasının, vasilerinin ya da kendisinden hukuken sorumlu olan diğer kişilerin hak ve ödevlerini de göz önünde tutarak, esenliği için gerekli bakım ve korumayı sağlamayı üstlenirler ve bu amaçla tüm uygun yasal ve idari önlemleri alırlar" denilmektedir. Bilindiği üzere, Anayasa’nın 90/V hükmü uyarınca, temel hak ve özgürlüklere ilişkin olan uluslararası anlaşmalar ve kanunlar arasında itilaf çıkması durumunda uluslararası anlaşmalar uygulanır. $\mathrm{Bu}$ durumda çocukları ilgilendiren hiçbir düzenlemenin çocuk hakları sözleşmesine aykırı olmaması gerekmektedir. Ayrıca kanunlar ve Çocuk Hakları Sözleşmesi'nin çakışması durumunda Çocuk Hakları Sözleşmesi hükümlerinin uygulanması gerekmektedir.

Çocuk Hakları Sözleşmesi'ne göre, çocuk yararına yorum yapılmalı ve ona göre karar verilmelidir. Hal böyle olunca, boşanma durumunda çocuğun annesinin veya babasının soyadını kullanılmaya başlaması çocuğun ruhsal,

Kanunu m.4/b'de düzenlenmektedir.

59 Bu ilkenin Türk hukukunda da uygulandığını gösteren yargı kararları için bkz. 2. HD., E. 2016/22821, K. 2018/9412, T. 18.9.2018 (Lexpera, Erişim 5.11.2019); 2. HD., E. 2016/21850, K. 2018/8934, T. 11.9.2018 (Lexpera, Erişim 5.11.2019); 2. HD., E. 2016/24853, K. 2018/11255, T. 17.10.2018 (Lexpera, Erişim 5.11.2019).

60 BAYGIN, s. 271; SEROZANs.162; AKYÜZ, s.12.

61 ÖZTAN, s.866; 2. HD.,E. 2019/2834,K. 2019/5028, T. 29.4.2019 (kazanc1 Veri Taban1, Erişim 21.11.2019):"Velayet düzenlemesinde; çocukla ana ve baba yararının çatışması halinde asıl olan küçü̆g̈̈n yararını korumak ve geleceğini güvence altına almaktır. Çocuğun yarart ise; çocuğun bedensel, fikri ve ahlâki bakımdan en iyi şekilde gelișebilmesi ve böyle bir gelişmenin gerçekleştirilmesi için, çocuğa sosyal, ekonomik ve kültürel koşulların sağlanmış olmasıdır. Çocuğun bu konulardaki üstün yararını belirlerken; çocuk yetişkin biri olmuş olsaydl, kendisini ilgilendiren bir olayda, kendi yararı için ne gibi bir karar verebilecekti ise, çocuk için karar verme makamındaki kişinin de, aynı yönde karar vermesi gerekir. Yani çocuğun farazi düşüncesi esas alınmalıdı»"; 2. HD.,E. 2019/906, K. 2019/1745, T. 27.2.2019 (Kazanc1 Veri Tabanı, Erişim 21.11.2019). 
ahlâki ve toplumsal hayattaki durumunu ne derece etkileyeceği araştırılmalı ve çocuğun menfaati hangi soyadını kullanmada ağır basıyorsa o soyadının kullanılmasına karar verilmesi Çocuk Hakları Sözleşmesi'ne en uygun olan yoldur.

Çocuk Hakları Sözleşmesi'nin 7. maddesinde “Çocuk doğumdan hemen sonra derhal nüfus kütüğ̈̈ne kaydedilecek ve doğumdan itibaren bir isim hakkına, bir vatandaşlık kazanma hakkına ve mümkün olduğu ölçüde anababasın bilme ve onlar tarafindan bakılma hakkına sahip olacaktır" ifadesine yer verilmiştir. $\mathrm{Bu}$ ifadeden, iç düzenlemedeki hiçbir kanun hükmünün çocuğun ana veya babası tarafından bakımını zorlaştırmaması gerektiği anlaşılmaktadır. $\mathrm{Bu}$ durumda kanaatimizce, boşanma sonucunda ana ve çocuğun soyadının farklı olması hastane, sslah evi, okul ve otel gibi yerlerde zorluk çıkartıyorsa, çocuğun velâyetini elinde bulunduran annenin soyadını alması Çocuk Hakları Sözleşmesi açısından en isabetli olan çözümdür. Bu durumda Yargıtay'ın, kamu düzenini ileri sürerek çocuğun annenin soyadını alamayacağını belirtmesi, Çocuk Hakları Sözleşmesi’ne aykırı olmaktadır.

Çocukların velayetinin annede kalması durumunda, anne ve çocuğun soyadının farklı olması, çocukların ruhsal travma yaşamasına sebep olabilmektedir. $\mathrm{Bu}$ durumda çocuğun soyadının değiştirilerek annesinin soyadını alamaması çocuğun menfaatini ihlâl edecektir ${ }^{62}$.

\section{b. Eşitlik İlkesi Uyarınca Değerlendirme}

Eşitlik ilkesi, hem başlı başına bir hak, hem de diğer insan hak ve özgürlüklerinden yararlanılmasına hakim, temel bir ilke olarak kabul edilmektedir. Anayasa'nın 10. maddesi eşitlik ilkesinden faydalanacak kişi ve ilkenin kapsamı konusunda bir sınırlama getirmemiştir. Anayasa'nın 10. maddesi "ayrımcılık yasağı" biçiminde düzenlenmemiş olsa bile eşitlik ilkesinin, anayasal bağlamda her durumda dayanılacak normatif bir değer taşıması nedeniyle, ayrımcılık yasağının da etkili bir şekilde hayata geçirilmesi gerekir $^{63}$.

AİHM içtihadında ${ }^{64}$ ise ayrımcılık yasağı, nesnel ve makul bir gerekçe olmaksızın, konuyla ilgili olarak benzer durumda olan kişilere farklı

62 TACIR, s. 50.

63 AYM, E. 1996/15, K. 1996/34, 23/9/1996 (Kazancı Veri Taban1, Erişim 6.11.2019).

64 Bkz. S.A.S v. France, Başvuru no. 43835/11; Sejdić ve Finci v. Bosna-Hersek, Başvuru no. 27996/06. 
muamelede bulunulması şeklinde tanımlanmaktadır.

Avrupa İnsan Hakları Sözleşmesi'nin 14. maddesinin diğer bağımsız maddeler tarafından güvence altına alınan hak ve özgürlüklerin kullanılmasında ayrımcılığa karşı koruma sağladığını, ancak her farklı muamelenin bu maddeye aykırı olmayacağını, eş değer ya da benzer bir konumdaki diğer bireylere imtiyazlı muamele yapıldığının ve bu farkın ayrımcılık teşkil ettiğinin kanıtlanmasının gerekli olduğunu, bu kapsamda farklı bir muamelenin 14. maddeye aykırı olması için nesnel ve makul bir nedeninin olmaması gerektiğini, böyle bir nedenin varlığının demokratik toplumlarda geçerli olan ilkelere göre değerlendirileceğini, bu bağlamda Sözleşme'nin güvenceye aldığ 1 bir hakkın kullanımındaki farklı bir muamelenin meşru bir amacı olmasının da yeterli olmadığını, bunun yanı sıra kullanılan yöntem ile gerçekleştirilmesi istenilen amaç arasında makul bir oransal bağ olmasının da zorunlu olduğunu belirten Mahkeme, taraf devletlerin, benzer durumlar arasındaki farklılıkların hangi hâllerde farklı bir muameleyi gerekli kıldığını belirlemede bir dereceye kadar takdir hakkına sahip olduğunu, bununla birlikte önemli bir ayrımcılık temeli olan cinsiyete dayalı farklı bir muamelenin Sözleşme'ye uygun olduğunun kabul edilebilmesi için çok geçerli nedenler sunulması gerektiğini vurgulamaktadır. Çocuğun sadece babanın soyadını alabileceğini kabul etmek ise eşitlik ilkesine aykırı olacaktır. Bu sebeple Yargıtay'ın tutumu eşitlik ilkesine de aykırıdır.

\section{c. Özel Hayatın Gizliliği İlkesi Uyarınca Değerlendirme}

Anayasa Mahkemesi, çocuğun soyadının velâyet hakkının sahibi anne ile farklı olması durumunda, özel hayata saygı ilkesinin ihlâl edilebileceğini kabul etmiştir. Kanaatimizce bu görüş, isabetli bir görüştür. Zira çocuğun soyadının anne ile aynı olmaması durumunda, aile hayatının gizliliği ihlâl edilebilir. Pek çok devlet kurumunda, aile olunduğunun kanıtlanması için ayrıca bir çaba sarf edilmesi gerekebileceği gibi, bireylerin herkesin gözünden uzak ve ev hayatı olarak tabir edebileceğimiz hayatları da etkilenebilir. Örneğin, daha önce de belirtildiği üzere, velayeti elinde bulunduran anne ve çocuğun soyadı farklı olunca, çocuklar aile oldukları bilincini pekiştiremeyebilirler. Burada çocuğun yararı gözetilmelidir. Çocuğun aile hayatı ihlâl ediliyorsa, boşanma sonrası çocuk annesinin soyadını alabilmelidir.

Avrupa İnsan Hakları Sözleşmesi’nin 8. maddesinde “Herkes özel ve aile hayatına, konutuna ve yazışmasina saygı gösterilmesi hakkına sahiptir" ifadesine yer verilmiştir. Aile, kadın ve erkek ile ebeveyn ve çocuk arasındaki 
ilişki olarak tanımlanabilir. Diğer bir ifade ile boşanma sonucu velayet annede kalmışsa bir aile yaşamının kurulması için yeterli şartlar sağlanmıştır denebilir. Zira aile olabilmek için anne, baba ve çocuk üçlemesine gerek yoktur. Nitekim AİHM'de vermiş olduğu bir karada boşanma davası sonucunda velayet hakk1 kendisine tevdi edilmiş olan başvurucu ile çocuk arasındaki ilişkide aile yaşamının kurulması için yeterli olacağını belirtmiştiir ${ }^{65}$.

Ebeveyniler ile çocuklar arasındaki ilişki, hukuken korunan önemli bir ilişkidir. Bu ilişki, sadece bir hukukî ilişki değildir; aynı zamanda bir duygusal ilişkidir ${ }^{66}$. Çocukların üstün yararı, çocuğun hayatı gibi pek çok etkenin bu ilişkide yer aldığı görülmektedir. Zira Yargıtay da bir kararında "Her ne kadar analık ve babalı duyguların tatmin de önemli bir faktör ise de çatışma haline çocuğun yararın üstün tutmak zorunludur" ifadesine yer vermiştir $^{67}$. Bu durumda, çocuğun annesinin soyadını alıp alamamasında, özel hayatın gizliliği ilkesine aykırılığın olup olmadığı, çocuğun özel hayatının gizliliğine müdahale edilip edilemediği şeklinde anlaşılmalıdır. Zira çocuk üstün olarak korunmalıdır. Soyadının aynı olmaması, çocuğun ve velayeti elinde bulunduran annenin özel hayatını etkileyebildiği görülmektedir. İşte bu gibi durumlarda, çocuğun özel hayatı için annesinin soyadını alması uygun olarak değerlendirilmelidir.

\section{Erkeğin Soyadı}

Evlilik durumunda kadın veya erkek bir soyadını ortak kullanmak zorundadır. Uygulamada genellikle kadının erkeğin soyadını aldığ1 görülmektedir. Ancak erkeğin de karısının soyadını almayı tercih edebileceği ve buna hukuken bir engelin bulunmadığı kanaatindeyiz.

TMK. m. 187'de, evlenme sonucu kocanın soyadının aile soyadı olmas1 gerektiği düzenlenmiştir ${ }^{68}$. Ayrıca söz konusu düzenleme emredici nitelikte olduğu için taraflarının bunu üzerinde tasarruf edebilme hakları da bulunmamaktadır ${ }^{69}$. Kanaatimizce bu durum, eşitlik ilkesine aykırıdır. $\mathrm{Bu}$ sebeple, erkeğin de evlenince karısının soyadını alabilmesi gerektiğini, hatta bekârken kullandığı soyadı ile birlikte karısının soyadını taşıyabilmesi

\footnotetext{
65 DURSUN, s.201.

66 SERDAR, s. 739.

67 2. HD.,E. 2000/7431, K. 2000/8396,T. 20.6.2000 (Kazanc1 Veri Tabanı, Erişim 21.11.2019).

68 DURAL/ÖĞÜZ/GÜMÜŞ, s. 155.

69 DURAL/ÖĞÜZ/GÜMÜŞ, s. 155.
}

Ankara Hacı Bayram Veli Üniversitesi Hukuk Fakültesi Dergisi C. XXIV, Y. 2020, Sa. 121 
gerektiğini düşünmekteyiz.

Türk hukukunda evlenme ile erkeğin soyadı değişmemektedir. Hatta erkeğin bunu talep etmesi durumunda dahi nüfusta bu işlemin yapılmadığı görülmektedir. Ancak erkeğin de kadının soyadını alma hakkına sahip olması gerekir. Türk yargısının önüne gelen bir olayda Türk vatandaşı bir erkek İsviçre vatandaşı bir kadınla evlidir. İsviçre' de evelenen çift ailenin ortak soyadı olarak kadının soyadını seçmişlerdir. Türk vatandaşı olan erkek bekârlık soyadını terk ederek İsviçreli karısının soyadını kullanmaya başlamıştır. Ancak Türkiye' deki yazışmalarda bekârlık soyadı göründüğü için bu durumunun değiştirilmesini ve Kırgız olarak gözüken soyadının Vollenweider olarak düzeltilmesini talep etmek üzere İstanbul 11. Asliye Hukuk Mahkemesine dilekçe vermiştir ${ }^{70}$. İlk derece mahkemesi, erkeğin soyadının değiştirilmesi ve karısının soyadını almasını hukuka uygun bulurken kamu yararı adına Cumhuriyet Savcılığı temyiz yoluna gitmiştir. Bunun üzerine mahkeme, erkeğin karısının soyadını almasının kamu düzenine aykırı olduğuna karar vermiştir ${ }^{71}$. Söz konusu kararın hukuka aykırı olduğu kanaatindeyiz. Zira 2001 tarihinde yürürlüğe giren TMK ve Anayasa, kadın-erkek eşitliğini sağlama amacı gütmektedir ${ }^{72}$. Kadın evlenince erkeğin soyadını alabiliyorsa, erkeğin de, eşitlik ilkesi gereği kadının soyadını alabilmesi gerekmektedir. Ayrıca kadın-erkek eşitliği kamu düzenindendir. O halde söz konusu kararın gerekçesi de kabul edilemez.

Türk hukuku, kadına eşinin soyadının yanında bekârlık soyadını da kullanabilme imkânını vermiştir. Ancak böyle bir imkân erkeklere verilmemiştir. Bizce bu uygulama da eşitliğe aykırıdır. Erkeklerin istemleri halinde eşlerinin soyadlarını alma veya eşlerinin soyadlarının yanında bekârlık soyadlarını kullanma hakkının da olması gerekir. Kadın-erkek eşitliğinin tam anlamıyla sağlanabilmesi için, kanun koyucunun erkeğin de eşinin soyadını alabileceğini düzenlemesi önem arz etmektedir.

\section{Soyadı Sorununa Bir Çözüm: Ortak Soyadı}

\section{Genel Olarak}

Aile, bir toplumdaki en önemli sosyolojik kümedir. Aileyi tıpkı bir hücreye benzetebiliriz. Nasıl hücreler bir araya gelip dokuları oluşturuyorsa; aileler de

70 ESEN, s. 439 vd.

71 Karar için bkz. ÇELİKEL/NOMER, , s. 473-475; 18.HD. E.288/1997. K.1496/1997, T.25.2.1997; ESEN, 439.

72 ESEN, s. 449. 
bir araya gelip toplumu oluşturur. Ayrıca, nasıl ki bir hücredeki huzursuzluk diğer hücreyi de etkiliyorsa, bir ailedeki yapıda toplumu etkiler. Bu sebeple, aileye ilişkin her türlü düzenleme aynı zamanda kamu düzeni kavramı ile de ilişkilidir. Her ne kadar bireyin ön plana çıktığı, bireyin haklarının toplumdan korunması gerektiği genel olarak kabul edilse de, bazı hallerde bireyler için toplumun düşünülmesi ve korunması da gerekmektedir.

Soyadı da kamu düzenin sağlanması ve aile birliğinin kurulması adına önemli bir rol oynar. Bu nedenle, ailenin ortak bir soyadının olması gerektiğini düşünmekteyiz.

\section{Eşlerin Soyadları Üzerindeki Etkisine Göre Soyadları Sistemleri}

\section{a. Genel Olarak}

Evliliğin karı ve kocanın soyadı üzerindeki etkisi, iki tür sistemi doğmuştur. Bunlardan birincisi, ailenin ortak bir soyadının olmasının gerekmediği sistem; ikincisi ise, ailenin mutlaka ortak bir soyadının zorunlu olduğu sistemdir ${ }^{73}$.

Ortak bir aile soyadının zorunlu olmadığı hukuk sistemleri bulunmaktadır. $\mathrm{Bu}$ sistemler, bireyselleşme akımlarından etkilenmiştir. Buna göre, aile birliğinin ortak bir soyadı ile temsil edilmesi gerekli değildir. Örneğin; Almanya, Avusturya, Fransa, İtalya ve 01 Ocak 2013 tarihinden itibaren İsviçre hukukunda kabul edilen uygulamaya göre ailenin ortak soyadının olması zorunlu değildir ${ }^{74}$.

Bazı sistemlerde ise ailenin ortak bir soyadı ile temsil edilmesi gerektiği kabul edilmiştir. Örneğin, Türk hukukunda ailenin zorunlu bir ortak soyadının olması gerektiği kabul edilmiştir. Ancak Türk hukuku, ataerkil zihniyettin etkisi altında kalarak sadece erkeğin soyadının ortak soyadı olabileceğini kabul etmiştir.

\section{b. Ortak Soyadı}

Her ne kadar bireyselleşen dünyada, bireyin hakları üstün tutulsa da, bazen toplum düzeni bireyin haklarını korumak adına üstün tutulmalıdır. Toplum ve birey arasındaki dengeyi korumak adına kamu düzeni kavramı ortaya çıkmıştır.

\footnotetext{
73 AYAN, s. 40.

74 AYAN, s. 40.
} 
Kamu düzenin tam anlamıla bir tanımı olmamakla birlikte, kamu düzeni, ülkedeki kurum ve kuralların işlerliğini, devletin güvenliğini, kamu hizmetlerinin iyi işlemesini sağlamak ve insanlar arasındaki ilişkilerde huzuru oluşturmak, kuralların hukuk ve ahlâk kurallarına uygunluğunu sağlamak amacıyla oluşturulan düzen olarak tanımlanabilir ${ }^{75}$. Diğer bir anlatımla kamu düzeni, toplumun genelini için var olan uyum halidir. Bu sebeple kamu düzeni kaynă̆ını toplumun yapısı ve adetlerinden de alır. Nitekim Yargıtay da bir kararında şöyle ifade etmiştir: "Türk hukukunun temel değerleri, Türk genel adap ve ahlâk anlayışı, Türk Kanunlarının dayandĭ̆ı temel adalet duygusu ve genel siyaseti, Anayasada yer alan temel hak ve özgürlükler, milletlerarası alanda geçerli ortak ve özel hukuka ait iyiniyet prensibine dayanan kurallar, medeni toplulukların müstereken benimsedikleri ahlâk ilkeleri ve adalet anlayışının ifadesi olan hukuk normları, toplumun medeniyet seviyesi, siyasi ve ekonomik rejim ile insan hak ve özgürlükleri, millî hukukumuzdaki kamu

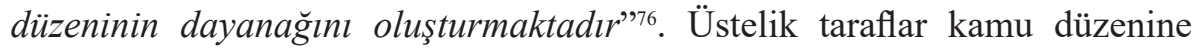
uymak zorundadır ve kamu düzeni ile ilgili konularda tarafların serbestçe tasarruf etme hakk1 da bulunmamaktadır ${ }^{77}$.

Soyadı da kamu düzeni ile ilgilidir. Zira soyadı, kültürümüzde aileyi tanımlayan ve ona aidiyet hissi veren bir kavramdır. Bu nedenle soyadının kamu düzeninden kabul edilmesi gerekir. Bir aileyi belirtmekte soyad1 kullanılmaktadır. Üstelik soyadı ailedeki aidiyet duygusunu da pekiştirmektedir. Ortak bir soyadının bulunmaması durumunun geleneklere aykırılık teşkil edeceği ve toplumda bir huzursuzluğa sebep olabileceği ve devlet kurumlarındaki işleyişe negatif etki edebileceği kanısındayız. Avrupa Bakanlar Komitesi, vermiş olduğu bir tavsiye kararında, soyadına ilişkin gelenekler ve yerel adetlere dayanan farklı yasal sistemler bulunsa da bu sistemlerin ayrımcı hükümler içermemesi durumunda kabul edilebileceğini

75 ÇELIK-ŞEŞEN, s. 15; HGK., E. 2011/568, K. 2012/47, T. 8.2.2012 (Lexpera, Erişim 7.11.2019): "Kamu düzeni doktrinde genel olarak, "bir toplumun, belirli bir zaman dilimi içerisinde, siyasi, sosyal, ekonomik, ahlâki ve hukukî açılardan temel yapısını belirleyen ve temel çıkarlarını koruyan kurum ve kurallar bütünüdür." șeklinde tanımlanmaktadır. (Süha Tanrıver, "Yabancı Hakem Kararlarının Türkiye'de Tenfizinde Kamu Düzeninin Rolü, Prof. Dr. Ali Bozer'e Armağan”, “Kamu Düzeni", Ankara, 1988, sh.152)”; Anayasa Mahkemesi'nin 28.1.1964 tarih ve E.1963/128, K.1964/8 say1l kararı (Kazanc1 veri Taban1): "...kamu düzeni deyiminin, toplumun dirlik ve düzenliğinin săglanmasını, Devletin ve Devlet kuruluşlarının korunmasını hedef tutan her şeyi ifade ettiği, bir başka deyimle, toplumun her sahadaki düzeninin temelini oluşturan bütün kuralları kapsadiğı kuşkusuzdur...”.

76 Bkz. 18. HD., E. 2013/16914, K. 2014/5145, T. 20.3.2014 (Lexpera, Erişim 7.11.2019).

77 YILMAZ, s.152. 
öngörmüş̧ür ${ }^{78}$. $\mathrm{O}$ halde Türk toplumunda geleneklerin devam edilip ailenin ortak bir soyadı ile temsil edilmesi gerektiği ve çocukların da bu ortak soyadını alması gerektiği, ancak bu düzenlemenin ayrımcılık oluşturmamasına dikkat edilmelidir. Zira bir hukuk devletinde bir kısma ayrımcılık yapılması kabul edilemez ${ }^{79}$.

Türk hukukunda mevcut sistem, ortak soyadını öngörse de mevcut düzenlemeler isabetsizdir. Bunun sebebi, Türk hukukunda ataerkil zihniyetin devam ederek sadece erkeğin soyadının ortak soyadı olabileceğinin kabul edilmesidir. Bu uygulama cinsiyet eşitliğine aykırıdır. Kanaatimizce, ortak bir soyadı taşınması aile için önem arz eder ve kamu düzeninin bozulmaması için önemlidir. Ancak sadece erkeğin soyadının alınması, hukuka uygun değildir. Zira Anayasa'nın 10. maddesinde herkesin, dil, rrk, renk, cinsiyet, siyasi düşünce, felsefi inanç, din, mezhep ve benzeri sebeplerle ayırım gözetilmeksizin kanun önünde eşit olduğu ve kadınların ve erkeklerin eşit haklara sahip olduğu düzenlenmiştir. Devletin yegâne görevi, bu eşitliğin yaşama geçmesini sağlamaktır. Bu durumda evli kadının soyadının açık rızası olmadan değişmesini bir zorunluluk olarak göstermek kabul edilir değildir. Zira Avrupa Birliği Bakanlar Komitesi de vermiş olduğu bir kararında, eşlerden birinin kendi soyadını değiştirerek diğerinin soyadını almasını yasal bir zorunluluk olmaktan çıkartmak üzere bir düzenlemeye gidilmesi ve bu yapılırken bazı örnek sistemlerin benimsenmesi gerektiği belirtilmiştir. $\mathrm{Bu}$ sistemler kararda şöyle belirtilmiştir: "Eşlerin ortak bir soyadl, özellikle de eşlerden birinin soyad, her iki eşin soyadlarının birleştirilmesiyle oluşan bir soyadı ya da her iki eşe de ait olmayan bir soyadı üzerinde anlaşmasl; her iki eşin de evlilikten önceki soyadlarını değiştirmemesi; yasalar uyarınca ortak soyadının her iki eşin soyadlarının birleştirilmesi suretiyle oluşturulması"”o.

Kanaatimizce, aileyi oluşturan kadın ve erkek soyadını seçme konusunda özgür olmalıdır. Kadının veya erkeğin soyadını alma konusunda bir tercih haklarının verilmesi gerekmektedir. Nitekim bazı hukuk sistemleri, eşlerin ortak soyadı taşıma zorunluğunu getirmesine rağmen eşlerin ortak soyadlarını seçebileceğini de düzenlemiştir ${ }^{81}$.Örneğin, 31 Aralık 2012 tarihine

\footnotetext{
78 Bkz. 28 Nisan 1995 tarihli ve 1271 (1995) sayılı Tavsiye Kararı ve 27 Ekim 1978 tarihli 878) 37 say1l karar.

79 ANAYURT, s. 448-449.

8027 Ekim 1978 tarihli 878/ 37 sayılı karar, ayrıca Bkz. Ünal Tekeli vs Turkey davası.

81 AYAN, s. 40.
} 
kadar İsviçre'de uygulama böyleydi. İsviçre'de aileler kadının veya erkeğin soyadını ortak soyadı olarak seçebiliyordu ${ }^{82}$. Türkiye'de toplumların gelenek ve görenekleri, aile yapısı ve devletin işleyişi göz önünde bulundurulduğunda ortak bir soyadının olması gerektiği açıktır. Ancak eşitlik ilkesi gereği, kadının veya erkeğin soyadının hangisinin ailenin ortak soyadı olacağı seçimlik hak olarak taraflara verilmelidir. Aksi haldeki durum, Anayasada yer alan ayrımcılık yasağına aykırılık teşkil eder.

Ortak soyadını savunmamızın altında yatan bir diğer etken ise aile kütükleridir. Aile kütükleri bireylerin adlarının, soyadlarının, anaların ve babaların ve büyükanne ve büyükbabalarının adlarını, soyadlarını, sağ olup olmadıklarını ve bunun gibi kişinin bilgilerini içeren kütüktür ${ }^{83}$. Soyadı üzerinde yapılan değişiklikler, aile kütüklerinin düzgün tutulmasını olumsuz etkileyebilir. $\mathrm{Bu}$ da kişinin soyunu öğrenmesini engelleyebilir. Ayrıca aile kütüklerinde yaşanacak bir sorun ensest aile ilişkilerin artması sonucunu da doğurabilir. Bu yöndeki kaygılarımızda ortak soyadının olması düşüncesini benimsememize neden olmuştur.

\section{Sonuç}

Bir aileye verilen ve bir kimsenin öz adından sonra kullanılan, kişilerin soyunu belirlemeye yardımcı olan ve kanun gereği taşınması zorunlu olan ada soyadı denilmektedir. Soyadının kullanılmasının altında yatan amaç ise kişileri ayırt edebilir kılmak, aileyi belirlemede kolaylık sağlamak, toplumsal düzeni sağlamak ve kişide aidiyet duygusunu pekiştirmektir.

Kadının, erkeğin ve çocuğun soyadlarına ilişkin farklı düzenlemeler ve yargı kararları bulunmaktadır. Bu nedenle kadının, erkeğin ve çocuğun soyadı ayrı ayrı ele alınması gereken konulardır. Kadının soyadının evlenince eşinin soyadı olması gerektiği Türk hukukunda kabul edilen bir yaklaşımdı. Daha sonra, kadının bekârlık soyadını da kocanın soyadı ile birlikte kullanabileceğine ilişkin düzenlemeler yapılmıştır. Ancak evliliğin kadının soyadını değiştirmemesi gerektiği düşüncesi ile AHIM'e yapılan başvurular kabul edilmiştir. AHİM, evliliğin soyadını değişmesi sonucunu doğurmaması gerektiği yönünde kararlar vermiştir. Buna rağmen Türk hukukunda, ortak soyadının kullanılması zorunluluğu değiştirilmemiştir.

\footnotetext{
82 AYAN, s. 40; BAŞAKOĞLU, s.369 vd.

83 ÖZTAN, s. 205.
}

26 Ankara Hacı Bayram Veli Üniversitesi Hukuk Fakültesi Dergisi C. XXIV, Y. 2020, Sa. 1 
Çocuğun soyadı ise, ailesinin evli olup olmamasına göre düzenlenmiştir. Kanun çocuğun soyadını evlilik içinde doğup doğmamasına göre farklı düzenlemiştir. Ayrıca kanun evlat edinilen çocuğun soyadına ilişkin de düzenlemeler öngörmüştür. Çocuğun soyadına yönelik tartışma, boşanma sonucu çocuğun soyadının değişip değişemeyeceğine yöneliktir. Anayasa Mahkemesi kadın-erkek eşitliği, aile hayatına saygı gibi ilkeleri ileri sürerek boşanma sonucu velayeti elinde bulunduran annenin çocuğun soyadını değişmesini talep edebileceğini kabul etmiştir. Söz konusu karar isabetli de olsa gerekçesinde bazı hukukî sorunlar taşımaktadır. Zira çocuğun olduğu bir birimde çocuk hukukuna göre gerekçe yazılmalıdır. O halde çocuğun menfaatine göre çocuğun soyadının boşanma ile değişebileceğinin kabulü gerekir.

Erkeğin soyadı ise üzerine düşünülmesi gereken diğer bir hukukî konudur. Zira evlenme sonucu kadınlar eşlerinin soyadlarını alabilirken erkeklere bu hak açıkça tanınmamıştır. Bu durum kadın-erkek eşitliği açısından sorunludur. Erkeğinde eşinin soyadını alabilme hakkı bulunmalıdır.

Kadın, erkek ve çocuk üçgeninde soyadı sorununa getirilebilecek en iyi çözüm yolu ortak soyadı sistemini devam ettirmektir. Ancak mevcut ortak soyadı sistemi değiştirilmelidir. Bu çalışmamızda kamu düzeni, ailenin korunmas1 gibi sebeplerle ortak soyadının olması gerektiği, ancak mevcut sistemin ve algının değişmesi gerektiği savunulmuştur. Kanımızca, erkek de karısının soyadını alabilir veya kadında erkeğin soyadını alabilir. Ancak, mutlaka bir ortak soyadında kadın ve erkek birleşmelidir. Çocuklarda evlilik birliği süresinde ailenin ortak soyadını taşımalıdır. 


\section{KAYNAKÇA}

ABİK, Yıldız: Kadının Soyadı ve Buna Bağlı Olarak Çocuğun Soyadı, Ankara 2005.

ACABEY, Beşir: Türk Hukukunda Aile Adı (Eşlerin ve Çocukların Soyadı), D.E.Ü Hukuk Fakültesi Dergisi, Prof. Dr. Şeref Ertaş'a Armağan, C. 19, 2017.

AKKAYAN-YILDIRIM, Ayça: Evlilik Dışı Çocuğun Soyadı ve 02.07.2009 Tarih 2005/114 E. 2009/105 K. Sayılı Anayasa Mahkemesi Kararının Bu Bağlamda Değerlendirilmesi, Prof. Dr. Rona Serozan'a Armağan, C. I, İstanbul 2010.

AKYÜZ, Emine: Çocuk Hukuku,6.B., İstanbul 2018.

ANAYURT, Ömer: Anayasa Hukuku Genel Kisımlar,2.B., Ankara 2018.

APAYDIN-ÖCAL, Bahadır: Son Yargı Kararları Işı̆̆ında Kadının Soyadı Meselesi Çözüme Kavuşturtuldu mu?, İnönü Üniversitesi Hukuk Fakültesi Dergisi, C. 6, Sa. 2, 2015.

ATASAYAN, Gözde: Kadının Soyadı Da Yok”, Prof. Dr. Mustafa Dural'a Armağan, İstanbul, 2013.

AYAN, Serkan: Anayasa Mahkemesi Kararları ve Çocuklar ile Kadının Soyadına İlişkin Değişiklik Tasarısı Taslağı Işı̆̆ında Soyadının İlk Kez Edinilmesi, Kendiliğinden Değişmesi ve Değiştirilmesi, Gazi Üniversitesi Hukuk Fakültesi Dergisi, C. XVI, Sa. 4, 2012.

BAKIRCI, Kadriye: İstanbul Sözleşmesi, Ankara Barosu Dergisi, Sa.4, 2015.

BALSOY, Gülhan: Meltem Türköz. Naming and Nation-Building in Turkey: The 1934 Surname Law, New York, Palgrave Macmillan, 2017, xiv 213 pages. New Perspectives on Turkey.

BAŞOĞLU, Başak: Soybağının Çocuğun Soyadına Etkisi, İnönü Üniversitesi Hukuk Fakültesi Dergisi, C.8., 2017.

BAYGIN, Cem: Soybağı Hukuku, 1.B., İstanbul 2010.

ÇELIK-ŞEŞEN, Hülya: Kamu Düzeni Kavramının Dirlik ve Esenlik Unsuru, 1.B., Ankara 2018.

ÇELIKEL, Aysel/NOMER, Engin: Devletler Hususi Hukuku-Örnek Olaylar- 
Mahkeme Kararları, 7.B., İstanbul 2001.

DEMIR, Nazlı Hilal: The Surname of Married Women: An Everlasting Problem, Fasikül Hukuk Dergisi, 2017, Sa. 88.

DURAL, Mustafa/ SARI, Suat: Türk Özel Hukuku Cilt 1, 9.B., İstanbul 2014.

DURAL, Mustafa/ÖĞÜZ, Tufan: Türk Özel Hukuku Cilt II Kişiler Hukuku, 15.B., İstanbul 2014.

DURSUN, Gizem: AİHM Kararları Işığında Özel hayata ve Aile Hayatına Sayg1 Hakk1, Bahçeşehir Üniversitesi Hukuk Fakültesi Dergisi, C. 13, Sa 167.

ESEN, Emre: Türk Vatandaşı Erkeğin Yabancı Eşin Soyadını Alamaması, MHB, Prof. Dr. Sevin Tolunere'e Armağan, sa 1-2, 2004.

ERDOĞAN, İhsan: Şahsiyeti İncitici Soyadı Meselesi, Selçuk Üniversitesi Hukuk Fakültesi Dergisi, C.6, Sa. 1-2, 1998, Prof. Dr. Süleyman Arslan'a Armağan.

GERMEÇ, Mahir Ersin: Çocuğun Soybağı ve Soyadı, Terazi Hukuk Dergisi, sa. $67,2012$.

GÖREN, Zafer: Anayasa Hukuku, 2.B. Ankara 2015.

GÖZTEPE, Ece: Anayasal Eşitlik İlkesi Açısından Evlilikte Kadınların Soyad1, AÜSBFD, C.54, Sa .2, 1999.

HATEMİ, Hüseyin/ KALKAN-OĞUZTÜRK, Burcu: Kişiler Hukuku, İstanbul 2013.

KILIÇOĞLU, Ahmet M.: Aile Hukuku, 2.B., Ankara 2016.

MEIER, Philippe/ STETTLER, Martin: Droit de la Filiation, 4.B., GeneveZurich 2009.

MOWAT, H. M.: The Law of Names, Canadian Law Times, 1900.

MOROĞLU, Nazan: Kadının Kimlik Sorunu "Kadının Soyadı", Türkiye Barolar Birliği Dergisi, Sa. 99, 2012.

OĞUZMAN, M. Kemal/ SELIÇĊ, Özer/OKTAY-ÖZDEMİR-Saibe: Kişiler Hukuku, 14.B., İstanbul 2014.

GENÇCAN, Ömer Uğur: Aile Hukuku, Ankara 2011. 
ÖZDAMAR, Demet: Kadın Hukuku Mevzuat1, 2.B., Ankara 2012.

ÖZTAN, Bilge: Şahsın Hukuku, 7.B., Ankara 1997.

ÖZTAN, Bilge: Aile Hukuku, 6.B., Ankara 2015.

SERDAR, İlknur: Kişisel İlişki Kurma Hakkı, Dokuz Eylül Üniversitesi Hukuk Fakültesi Dergisi Cilt: 9, Özel Sayı, 2007.

SEROZAN, Rona: Çocuk Hukuku, İstanbul 2005.

TACIR, Hamide: Evli Kadının Kendi Soyadını Kullanması Konusunda Anayasa Mahkemesinin Yaklaşımının Temel Hak ve Özgürlükler Bakımından Değerlendirilmesi, Kadir Has Üniversitesi Hukuk Fakültesi Dergisi, C. 5., sa.1, 2017.

ULUCAN, Devrim: Eşitlik İlkesi ve Pozitif Ayrımcılık, Dokuz Eylül Üniversitesi Hukuk Fakültesi Dergisi, cilt 15, 2013.

YILMAZ, Süleyman: Hukuk Başlangıcı, 1. B., Ankara 2019. 